Fauna and age. Generally the formation is not very fossiliferous, the fauna is mainly represented by scattered actinoceratid cephalopods, tabulate corals and stromatoporoids. A late Ordovician to early Silurian (Lower Llandovery) age is indicated.

Boundaries. The Aleqatsiaq Fjord Formation is conformable with the underlying Cape Calhoun Formation and with numerous overlying formations of both the Kap Constitution and Washington Land Groups (Hurst, in press).

Distribution. Western and northern Washington Land. The formation has been recognised as far eastwards as Wulff Land (Hurst \& Peel, 1979).

Troelsen, J. C. 1956: Groenland. In Lexique Stratigraphique International 1 (1a), 116 pp. Paris: C.N.R.S.

\title{
References
}

Dawes, P. R. \& Haller, J. 1979: Historical aspects in the geological investigations of northern Greenland. Meddr. Grønland 200(4), $38 \mathrm{pp}$.

Hurst, J. M. in press: Silurian stratigraphy and facies distribution in Washington Land and western Hall Land, North Greenland. Bull. Grønlands geol. Unders.

Hurst, J. M. \& Peel, J. S. 1979: Late Proterozoic(?) to Silurian stratigraphy of southern Wulff Land, North Greenland. Rapp. Grønlands geol. Unders. 91, 37-56.

Koch, L. 1920: Stratigraphy of Northwest Greenland. Meddr dansk geol. Foren. 5(17), 78 pp.

Koch, L. 1925: The geology of North Greenland. Amer. J. Sci. (5), 9, 271-285.

Koch, L. 1929a: Stratigraphy of Greenland. Meddr Grønland 73(2), 2, 205-320.

Koch, L. 1929b: The geology of the south coast of Washington Land. Meddr Grønland 73 (1), 1, $39 \mathrm{pp}$.

Norford, B. S. 1972: Silurian stratigraphic sections at Kap Tyson, Offley $\emptyset$ and Kap Schuchert, Northwestern Greenland. Meddr Grønland 195(2), $40 \mathrm{pp}$.

Teichert, C. 1937: A new Ordovician fauna from Washington Land, North Greenland. Meddr Grønland 119(1), $65 \mathrm{pp}$.

Troedsson, G. T. 1926: On the Middle and Upper Ordovician faunas of northern Greenland. I. Cephalopods. Meddr Grønland 71, 1-157.

Troedsson, G. T. 1928: On the Middle and Upper Ordovician faunas of northern Greenland. II. Meddr Grønland 72(1), 1, $197 \mathrm{pp}$.

Troelsen, J. C. 1950: Contributions on the geology of Northwest Greenland, Ellesmere Island and Axel Heiberg Island. Meddr Grønland 149(7), 29 pp.

Troelsen, J. C. 1956: Groenland. In Lexique Stratigraphique International 1 (1a), 116 pp. Paris. C.N. R.S.

\section{Acritarchs from the Proterozoic Thule Group, North-West Greenland}

\section{Gonzalo Vidal and Peter R. Dawes}

A thick sequence of Proterozoic sedimentary and volcanic rocks (the Thule Group), penetrated in part by basic minor intrusions, characterises the Thule district of North-West Greenland (fig. 6). These strata, overlying the Greenland Shield with profound unconfor- 


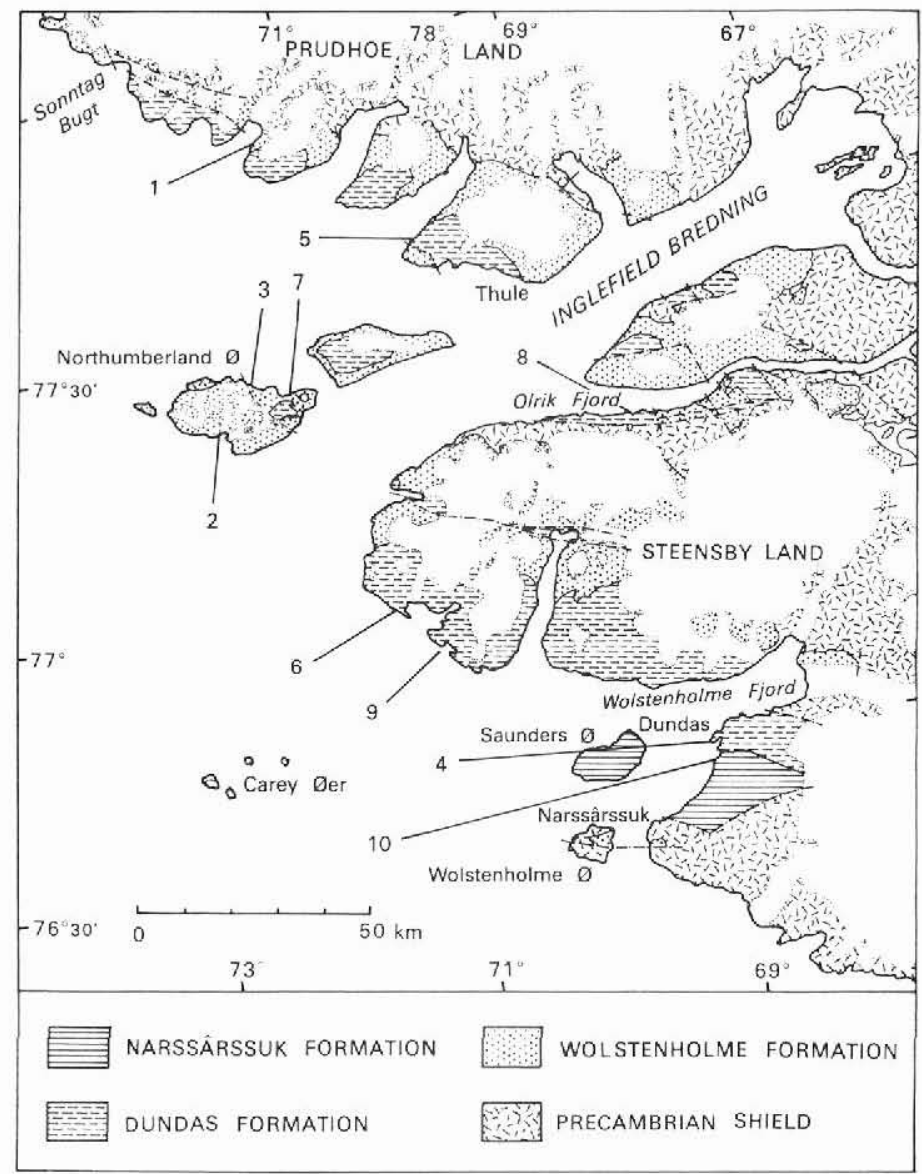

Fig. 6. Geological sketch map of the Thule district, North-West Greenland, illustrating the distribution of the three formations of the Thule Group and the locations of the acritarch and organic-bearing samples mentioned in the report. 1 - GGU 243474, 243477; 2 - GGU 212633; 3 - GGU 166179, 166180,$166183 ; 4$ - GGU 243560, 243561, 243566, 243567, 243580, 243582, 243586, 243587, 243591; 5 - GGU 140978; 6 - GGU 166626; 7 - GGU 212514; 8 - GGU 166148; 9 - GGU 166641; 10 - GGU 165803, 166695, 166696, 243202.

mity, form a large intracratonic basin on the northern margin of the North AmericanGreenland craton (Dawes, 1976).

The Thule Group, as presently known, reaches a composite thickness of $4.5 \mathrm{~km}$ and is divided into three main mappable units. The Wolstenholme Formation, the oldest unit, is composed of a sequence of sandstone, quartzite, conglomerate and volcanics with minor shale and siltstone. The Dundas Formation is mainly shale and siltstone with dolomite, while the Narssârssuk Formation is principally composed of carbonates, sandstone and red siltstone, with chert and evaporite. A stratigraphical revision of the Thule Group by one of us 
(PRD) is in preparation, but in the present report the terminology as used by Davies et al. (1963; Kurtz \& Wales, 1951) is retained.

The Wolstenholme Formation, overlies the crystalline basement, and passes gradationally upwards into the Dundas Formation, the upper boundary of which is not seen. The contact between the Dundas Formation and the Narssârssuk Formation is not exposed, but it is generally considered that much of the Narssârssuk Formation post-dates the Dundas Formation (Kurtz \& Wales, 1951; Davies et al., 1963). The presence of evaporite and chert at the top of the Dundas Formation suggests some gradation to Narssârssuk lithologies (Dawes, 1979). However, it is not known if the two latter formations in part represent two different facies of essentially contemporaneous sedimentation.

The Proterozoic age of the Thule Group has been determined by isotopic K/Ar age work on basic sills and dykes that cut the sedimentary beds. Results so far suggest that the lower part of the Wolstenholme Formation may be as old as 1200 m.y. and that the Dundas and Narssârssuk Formations are no younger than about 540 m.y. (Dawes et al., 1973).

The only known traces of organisms recorded from the Thule Group are stromatolites from all three formations, and worm-like traces from the lower two formations (Dawes \& Bromley, 1975). The present microfossil study was launched in an attempt to gain a more accurate dating of the Thule Group and is particularly concerned with the stratigraphical relationship between the Dundas and Narssârssuk Formations.

\section{The material}

The majority of the material processed was selected from sample collections assembled by PRD during regional geological studies. Some material from the 1977 and 1978 field seasons was specifically collected for microfossil analysis.

A total of 46 samples have so far been processed following the technique described earlier by Vidal (1976). Of these, 16 samples, mostly dark coloured shales and siltstones, were found to contain acritarchs or other microfossils. In some, acritarchs are extremely abundant and well preserved. Eight samples contain only unidentifiable organic detritus while the remainder (22) proved to be barren.

The locations of the samples are indicated on fig. 6 .

\section{Results and discussion}

The distribution of acritarch taxa from samples in the Thule Group is summarised in fig. 7 in which the samples are arranged in general stratigraphical order. However, the samples come from widely spaced localities throughout the Thule Basin (fig. 6) and the precise stratigraphical position of some samples is uncertain. Particularly noteworthy in this context is sample GGU 166148 that is placed in the uppermost part of the Dundas Formation mainly from the evidence of its acritarch content (see below).

Notes on the acritarch assemblage of each formation are given below; for detailed taxonomic comparisons the reader is referred to Vidal $(1974,1976,1979 b)$.

Wolstenholme Formation. The acritarch assemblage of this formation indicates a late 'Riphean' age (as used by Vidal, 1979a). The most important taxa are Kildinella hyperbore- 


\begin{tabular}{|c|c|c|c|c|c|c|c|c|c|c|c|c|c|c|c|c|c|c|c|}
\hline STRATIGRAPHIC UNIT & & & & $\begin{array}{l}\text { TEI } \\
\text { И. }\end{array}$ & & & & & & JND & DAS & s & FRM & & & & & & $\begin{array}{l}\text { ISS. } \\
\text { M. }\end{array}$ \\
\hline $\begin{array}{lr}\text { MICROFOSSIL - } & \text { GGU SAMPLE } \\
\text { ORGANIC CONTENT } & \text { NO. } \\
\end{array}$ & 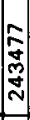 & & & $\frac{\infty}{0}$ & $\stackrel{\infty}{\infty}$ & & \begin{tabular}{|l}
+ \\
$\infty$ \\
$\infty$ \\
\\
0 \\
$\vdots$ \\
\\
\end{tabular} & 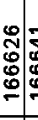 & & 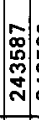 & & : & & & & $\mid$\begin{tabular}{l}
+ \\
$\infty$ \\
0 \\
$\vdots$ \\
0 \\
\hdashline \\
-1 \\
\end{tabular} & 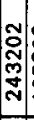 & & 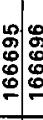 \\
\hline CHUARIA CIRCULARIS & & & 0 & 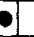 & $\bullet$ & e & & - & & $\bullet$ & & - & & - & & $\bullet$ & & & \\
\hline KILDINELLA spp. & & & & & & & & - & & & & & & & & & & & \\
\hline K. n. sp. VID. & & 0 & & & & & & & & - & & & & & & & & & \\
\hline K. HYPERBOREICA TIM. & $\bullet$ & - & - & 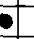 & 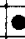 & 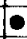 & & & & & -1 & - & & - & & e & & & \\
\hline K. SINICA TIM. & & 0 & -1 & 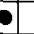 & 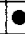 & 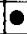 & & & - & - & 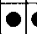 & - & & - & & e & & & \\
\hline PETEINOSPHAERIDIUM sp. & & & & & & & & & & & & & & & & - & - & & \\
\hline PROTOSPHAERIDIUM LACCATUM TIM. & & & & & & & & & & & & & & & & 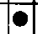 & & & \\
\hline TRACHYSPHAERIDIUM sp. & & & -1 & 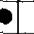 & e & & & - & & $\bullet$ & - & & & & & & & & \\
\hline T. TIMOFEEVI VID. & - & & & 5 & & & $\bullet$ & & & & & 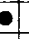 & & & & & & & \\
\hline TREMATOSPHAERIDIUM HOLTEDAHLII TIM. & & & & & & & $\bullet$ & & & & & & & & & & & & \\
\hline cf. STICTOSPHAERIDIUM sp. VID. & - & - & - - & 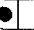 & 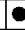 & $\bullet$ & & $\bullet$ & - & - & - & - & & - & & & & & \\
\hline SYMPLASSOSPHAERIDIUM sp. & & - & & & & & & & & & & & & & & & & & \\
\hline SYNSPHAERIDIUM sp. VID. & & & & & & & & 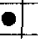 & & & & & & $\bullet$ & & & & & \\
\hline ACANTHOMORPH - LIKE ACRITARCH & & & & & & & & & & - & & & & & & & & & \\
\hline FILAMENTOUS MICROFOSSILS & & & & & & & & & & & & & & & & & $\boldsymbol{\bullet}$ & & \\
\hline ORGANIC REMAINS & & & & & & & - & & 0 & & & & 1 & & $\bullet$ & & & & - \\
\hline
\end{tabular}

Fig. 7. Microfossil data from the Thule Group. Samples are arranged from left to right in general ascending stratigraphical order. Samples marked by a cross indicate uncertain stratigraphic position.

ica, that is restricted to the Upper 'Riphean' and Vendian (Vidal, 1979a), Chuaria circularis, a common Upper 'Riphean' mega-acritarch, and Kildinella n.sp. This latter species (as yet undescribed) is particularly interesting and is diagnostic as to age since it is abundant in the Upper 'Riphean' Vadsö Group in East Finnmark, the base of which has a Rb/Sr age of 793 \pm 90 m.y. (Pringle, 1973; Vidal, 1979a). It is also abundant in the lower part of the upper member of the Båtsfjord Formation of the upper Barents Sea Group in easternmost Finnmark, the lower part of which has yielded a Lower Vendian acritarch assemblage (Vidal, in press). Other well represented taxa are cf. Stictosphaeridium sp. of very little diagnostic value, and Trachysphaeridium timofeevi with a stratigraphical range from the Upper 'Riphean' to Lower Cambrian.

The stratigraphically lowest acritarch-bearing sample so far discovered (GGU 243477) is from a siltstone and shale sequence in the northern part of the Thule Basin; the sequence is underlain by a thick succession of mainly detrital clastic rocks. Due to the presence of abundant igneous material, both effusive beds and intrusive sills, the precise thickness of the underlying sediments is uncertain, but at least several hundred metres of strata are involved. The age of this lower clastic succession is unknown but radiometric ages from dolerite sills around Sonntag Bugt and elsewhere (Dawes et al., 1973; and GGU unpublished) suggests that the lower part of the Wolstenholme Formation is at least 1200 m.y. old, i.e. middle 'Riphean' or even earlier (Helikian, in North American terms).

Dundas Formation. This formation contains many taxa common to the underlying Wolstenholme Formation, the most important being Kildinella hyperboreica, K. sinica, Kildinella n. sp., and Chuaria circularis. The acritarch assemblages occurring for example in 
samples GGU 243567, 243586 and 166626 are typically late 'Riphean'. Of the taxa not represented in the Wolstenholme Formation, Synsphaeridium sp. (not diagnostic), Protosphaeridium laccatum (long stratigraphical range from Lower Proterozoic to Ordovician), Trematosphaeridium holtedahlii (Upper 'Riphean', Vendian and Lower Cambrian(?)) and 'Peteinosphaeridium' sp., only the latter is of important stratigraphical value. This species has not yet been described (assignable to a new genus, see Vidal, in press) but it is common in rocks of the Ekkerøy Formation of the uppermost Vadsö Group and in the overlying Tanafjord Group in northern Norway and may be related to ' $P$ '. reticulatum Vidal, 1976 (Vidal, in press) from the upper unit of the Visingsö Group in southern Sweden. Only one sample of the Dundas Formation contains 'Peteinosphaeridium' sp. (GGU 166148, fig. 7) and this can be tentatively referred to the early Vendian (approximately $700 \mathrm{~m} . \mathrm{y}$;; Hadrynian on the North American scale).

The sequence of rocks in Olrik Fjord from which sample GGU 166148 is derived forms an isolated fault block bounded by Precambrian crystalline basement (fig. 6). The stratigraphical relationship of this sequence of rocks to the type area around Dundas village is as yet unknown, but at least $300 \mathrm{~m}$ of shales are present stratigraphically above the horizon from which GGU 166148 was collected. Thus, while the main part of the Dundas Formation is of late 'Riphean' age, it is possible that at least several hundred metres of rock in the uppermost part are of Vendian age.

Narssârssuk Formation. The red-bed, dominantly carbonate-sandstone-siltstone, lithology of this formation is not particularly conducive to acritarch preservation and only one sample of those processed contained acritarchs - 'Peteinosphaeridium' sp. As recorded above, the presence of this acritarch is thought to be indicative of an early Vendian age. The sample in question, GGU 243202, is taken from near the exposed base of the formation, and this suggests that all the formation is of Vendian age.

\section{Conclusions}

On the basis of the 16 acritarch-bearing samples from the Thule Group so far studied the following conclusions can be given.

1. The Thule Group contains strata of late 'Riphean' and early Vendian ages. The middle and upper part of the Wolstenholme Formation are of late 'Riphean' age; the Dundas Formation is of late 'Riphean' age probably ranging up into the early Vendian.

2. Although based on a single sample the Lower Red Member of the Narssârssuk Formation appears to be of early Vendian age and, on this evidence, the formation post-dates a substantial thickness (perhaps all) of the Dundas Formation.

3. No acritarch samples are yet known from the lower part of the Wolstenholme Formation, or the middle and upper units of the Narssârssuk Formation. Consequently, middle 'Riphean' or earlier beds (as suggested by the radiometric data) and later Vendian strata might be expected to be present.

4. Many of the acritarch taxa of the Thule Group are common in the Eleonore Bay Group of East Greenland (Vidal, 1979b), in the Visingsö Group of south central Sweden (Vidal, 1974, 1976) and in the Vadsö Group of East Finnmark and on the Russian Platform 
(Timofeev, 1969, 1973; Vidal 1979a and unpublished) providing further evidence to indicate the widespread occurrence of certain taxa and their importance in correlation of late Proterozoic strata throughout the Arctic.

\section{References}

Davies, W. E., Krinsley,D. B. \& Nicol, A. H: 1963: Geology of the North Star Bugt area, Northwest Greenland. Meddr Grønland 162(12), 68 pp.

Dawes, P. R. 1976: Precambrian to Tertiary of northern Greenland. In Escher A. \& Watt, W. S. (edit.) Geology of Greenland, 248-303. Copenhagen: Geol. Surv. Greenland.

Dawes, P. R. 1979: Field investigations in the Precambrian terrain of the Thule district, North-West Greenland. Rapp. Grønlands geol. Unders. 95, 14-22.

Dawes, P. R. \& Bromley, R. G. 1975: Late Precambrian trace fossils from the Thule Group, western North Greenland. Rapp. Grønlands geol. Unders. 75, 38-42.

Dawes, P. R., Rex, D. C. \& Jepsen, H. F. 1973: K/Ar whole rock ages of dolerites from the Thule district, western North Greenland. Rapp. Grønlands geol. Unders. 55, 61-66.

Kurtz, V. E. \& Wales, D. B. 1951: Geology of the Thule area, Greenland. Proc. Okla, Acad. Sci. 31 (1950), 83-92.

Pringle, I. R. 1973: Rb-Sr age determinations on shales associated with the Varanger Ice Age. Geol. Mag. 109, 460-465.

Timofeev, B. V. 1969: Sferomorfidy Proterozoya. [Proterozoic sphaeromorphs]. Akad. Nauk SSSR, Lab. Geol. Dokembr. Nauka: Leningrad.

Timofeev, B. V. 1973: Mikrofossilii dokembriya Ukrainy. [Microfossils from the Precambrian of Ukraine]. Akad. Nauk SSSR, Inst. Geol. Geokron. Dokembr. Nauka: Leningrad.

Vidal, G. 1974: Late Precambrian microfossils from the basal sandstone unit of the Visingsö beds, South Sweden. Geol. Palaeont. 8, 1-14.

Vidal, G. 1976: Late Precambrian microfossils from the Visingsö beds, South Sweden. Fossils Strata 9, $57 \mathrm{pp}$.

Vidal, G. 1979a: Acritarchs and the correlation of the Upper Proterozoic. Publ. Inst. Mineral. Palaeont. Quat. Geol. Univ. Lund 219, 22 pp.

Vidal, G. 1979b: Acritarchs from the Upper Proterozoic and Lower Cambrian of East Greenland. Bull. Grønlands geol. Unders. 134, 40 pp.

Vidal, G. in press: Micropalaeontology and biostratigraphy of the Upper Proterozoic and Lower Cambrian sequence in East Finnmark, northern Norway. Submitted to Norges Geologiske Undersøkelse.

G.V.,

Geologiska Institutionen, Lunds Universitet, Avd för Historisk Geologi och Paleontologi, Sölvegatan 13, S-223 62 Lund Sweden. 